\title{
PROBLEM OF FORMATION OF PEDAGOGICAL MODELING AS A PROFESSIONAL PORTRAIT OF THE EDUCATIONAL SYSTEM OF EDUCATIONAL REHABILITATION AGENCIES
}

\begin{abstract}
Summary
The article deals with the problem of the functioning of the modern educational system of educational and rehabilitation agencies in the conditions of dynamic changes in the educational sphere. A theoretical analysis of basic concepts was carried out, which showed the ambiguity of some provisions of the methodology of modeling of educational systems, including educational ones. The methodological principles of the modeling process of the educational system of the educational and rehabilitation institution are outlined. The interpretation of the concepts of «modeling», "pedagogical modeling» and distinguishing between them is carried out. Collected scientific researches and work of the leading teachers of the sphere. A systematic approach is taken out that allows to consider a simulated pedagogical object as a certain integrity, which acts as a complex and multidimensional pedagogical system.
\end{abstract}

Key words: modeling; pedagogical modeling; model; pedagogical model; educational process; modern educational institution; methodological basis; principles of pedagogy.

Rethinking the educational concept, updating the content, technologies of formation of the student's personality as a subject and designer of life, creating a productive educational system aimed at forming a competent, competitive personality who is able to solve problems creatively, seeks to change his life better and life of the whole country.

Today, the need to create unique educational systems for educational institutions, in particular educational and rehabilitation, where the educational process involves the creation of a special educational environment, saturated with elements of correctional content of means, methods and forms of organization of activities, is being updated.

To ensure the effective functioning of the educational space, unique educational systems of educational institutions are called, in the process of development of which the specific conditions, peculiarities, interests and needs of all subjects of the educational process are taken into account $[17 ; 18]$.

One of the leading methods of creating an educational system for educational and rehabilitation institutions is modeling, which allows to predict the development of the pedagogical process, orientates all participants in the educational process to achieve the ultimate results of educational work, provides assimilation and effective use of new technologies, develops a systemic vision of problem solving, serves an effective factor in improving the quality of work of an educational institution [19; 20].

The methodological basis for modeling educational, in particular educational systems, is actively developed by domestic and foreign scientists.

Some aspects of the content and organization of the modeling process, conditions for the implementation of models in the works of such scholars as Y. Babanskiy, L. Koval, V. Opachko, V. Maslov, E. Stepanov, S. Kasyarum, V. Shtoff, N. Sofronova, R. Gorokhov, V. Monakhov, O. Bezpalko, E. Yudin, N. Ostroverkhova, N. Selivanova and others.

The problems of creating a model of the educational system (for example, the division of spheres of education and education, modeling of personality, as a component of the educational 
system, the use of special methods in the process of modeling and implementation of model representations) are identified.

In scientific literature, the term «modeling» is considered to be the reproduction of the characteristics of an object on another object (model), which is specially created for study $[13$, p. $65 ; 14$, p. 169]. Identification of scientists:

1) Koval L. considers modeling as a method and a universal method of cognition used to study and transform phenomena in any field of activity [12, p. 498];

2) Novik I. under the modeling understands the method of indirect practical or theoretical operation of the object $[1$, p. $56 ; 2$, p. 42];

3) Opachko M. regards it as a process of layout, construction, schematization, ideal representation of the process, phenomenon, object [3, p. 278];

4) Maslov V. argues that modeling is not only a method but also a subsystem (independent stage) management;

5) Babansky Y. as a process of constructing and studying models of existing objects and phenomena and constructed objects.

Considering the interpretation of the concepts of «modeling» and «pedagogical modeling» by various researchers, we can state that they are used in broad and narrow sense in accordance with the subject of research.

The purpose of pedagogical modeling is to determine the possibilities of improving the pedagogical process, finding reserves to improve its quality and effectiveness on the basis of analysis of the proposed model. While the purpose of the simulation is more abstract and involves the creation of a model of the real object being investigated. The object of pedagogical modeling is the educational process.

The subject of pedagogical modeling are specific elements of the educational process. The object and subject of simulation are more abstract categories.

The main advantages of the simulation method are that it is possible to investigate phenomena and systems that are too complex in the objective reality, and the simulation provides additional cognition opportunities in the absence of the ability to directly study the object being studied or the phenomenon and the growth of a role theories in certain branches of science that can not be realized without the use of abstract concepts and terms.

The conditions for applying simulations are defined: first, when the object of knowledge existed in the past, and at the time of study it is not exist; and secondly, when the object of knowledge may exist in the future; Thirdly, when an object actually exists at the time of the study, it is either extremely complex or inaccessible to knowledge at all; Fourthly, when the process is proceeding either too fast or too slowly. In the monograph edited by N. Sofronova, the following types of simulation are distinguished: deterministic and stochastic, static and dynamic, discrete, continuous and discrete-continuous [4; 2, p. 61-63].

It is important to determine the main functions of the modeling: descriptive (helps to distinguish in the object being studied, the most significant features); constructive (allows the use of the results obtained in the new conditions) and heuristic (contributes to the prediction of the results of the study) [6, p. 83].

Buslova M. proposes to implement the simulation process in the following stages:

1) statement of the problem;

2) theoretical and experimental training;

3) creating a model;

4) model research;

5) transfer of received information to the investigated object;

6) the nomination of a scientific hypothesis based on the knowledge obtained and its verification;

7) inclusion of knowledge in the scientific theory [5, p. 156-157].

The construction of a pedagogical model is very similar to a managerial cycle and occurs 
through: the definition of goals, regularities, principles, definitions of content, forms, methods, control systems and the evaluation of the result.

The main stages of constructing a pedagogical model include.

The first stage: statement of the task. The correct definition of the task provides a solution to the managerial problem.

The second stage: the construction of the model. It provides for the collection of necessary information that will contribute to the achievement of a specific goal, the definition of information flows, the establishment of their dependence and interaction and the process of their structuring.

Stage three: verifying the model for reliability. After constructing the model, it is necessary to check the degree of conformity of the model to the real object. This occurs when analyzing all the components that affect the solution of the task.

The fourth stage: the implementation of the model, which involves determining the degree of success of the constructed model.

Fifth stage: updating the model. After testing the model, some of its components may require modifications.

The process of creating a pedagogical model should be based on the principles:

1) the principle of multifaceted description of the objects of the educational system;

2) principle of consistency in determining the structure of the object of modeling;

3 ) the principle of purposefulness and openness;

4) principle of causality and unity of the essence of the object of modeling;

5) the principle of the structural division of the object into its constituent elements;

6) the principle of the continuity of the development of the modeling object;

7) the principle of predictability;

8) the principle of the reliability of the description of the object being modeled;

9) the principle of variability;

10) the principle of informational sufficiency;

11 ) the principle of scientific and systematic;

12) the principle of specificity of reflection [3;19].

The model of the educational system of the educational and rehabilitation institution must meet the following requirements:

1) the model should be convenient for use;

2) the content of the model must be consistent with the environment in which it functions and is part of it;

3 ) the model should be adequate, that is, the determined goal should help to obtain the predicted result of the implementation of the model;

4) the model must be complete and accurate.

Summarizing the basic provisions of modeling theory, we can state that the concept of «pedagogical modeling», in contrast to «modeling», is narrower and more specific, and is used in the process of designing improvements in the educational system [6;7]. Despite some discrepancy in the interpretation and scale of the application of the phenomena studied, the result of both processes is the model.

Consequently, the foregoing allows us to draw the following conclusions. Simulation, as one of the main categories of the theory of knowledge uses specially constructed models that are studied to determine or refine the characteristics and rationalization of methods of constructing objects. Before the simulation is applied when it is necessary to design the investigated object, to make corresponding corrections after approbation $[8 ; 9]$.

In the process of creating the educational system of the educational and rehabilitation institution, simulation is one of the most optimal methods that allows to highlight the actual and perspective tasks of the educational process, to identify, study and scientifically substantiate the conditions for possible convergence between the probable, expected and desired changes of the 
subject being studied. The constituent parts of the simulation, as a procedural system, are: object and subject of modeling; the process of formation and implementation of model representations; model and results $[10 ; 11]$.

The components of the model of the educational system of the educational and rehabilitation institution are: the purpose, tasks, components and interrelations between them, the connection of the system with the external environment, types and forms of activity, criteria and indicators of the functioning of the system.

The peculiarity of the model of the educational system of the educational and rehabilitation institution is the clearly reflected systemic interconnection of its structural components.

\section{References}

1. Babansky, Yu.K. (1988). Pedahohika [Pedagogy]. Moscow. 479 p.

2. Bezpalko, O.V. (2015) Spektr kompetentnosti maibutnoho sotsialnoho pedahoha yak osnovy profesionalizmu [Competency spectrum of the future social pedagogue as the basis of professionalism]. Problemy osvity - Problems of education. Kyiv. No. 84, 60-64.

3. Bespalko, O.P. (1989). Systemno-metodychne zabezpechennia navchalno-vykhovnoho protsesu pidhotovky fakhivtsia [System-methodical maintenance of educational and educational process of training of a specialist]. Moscow. $144 \mathrm{p}$.

4. Bibik, S.P., \& Siuta, G.M. (2005). Slovnyk inozemnykh sliv. Interpretatsiia, slovotvorennia ta slovotvorennia [Dictionary of foreign words. Interpretation, word formation and word-formation]. Kharkiv. 623 p.

5. Buslova, M.K. (1975). Modeliuvannia v protsesi piznannia (na materialakh khimii) [Modeling in the process of knowledge (on materials of chemistry)]. Minsk. $160 \mathrm{p}$.

6. Velykyi poiasniuvalnyi slovnyk suchasnoi ukrainskoi movy [Great explanatory dictionary of modern Ukrainian language] (2005). V.T. Busel (Eds.), Kyiv. 1728 p.

7. Glinsky, B.A., Gryaznov, B S., Dinin, B.S., \& Nikitin, E.P. (1965). Modeliuvannia yak metod naukovoho doslidzhennia (hnoseolohichnyi analiz) [Modeling as a method of scientific research (gnoseological analysis)]. Minsk, $248 \mathrm{p}$.

8. Goncharenko, S.V. (2011). Ukrainskyi pedahohichnyi entsyklopedychnyi slovnyk [Ukrainian Pedagogical Encyclopedic Dictionary]. Rivne. 552 p.

9. Ivaschenko, K. Vyznachennia sutnosti poniattia «pedahohichna systema» [Definition of the essence of the concept of «pedagogical system»]. Retrieved from: http://dspace.udpu.org.ua:8080/jspui/ handle/6789/3628.

10. Kasyanenko, O.M. (2018). Formuvannia hotovnosti maibutnikh vykhovateliv do roboty z ditmy doshkilnoho viku $\mathrm{v}$ umovakh vkliuchennia [Formation of readiness of future educators for work with children of preschool age in conditions of inclusion]. Extended abstract of candidate's thesis. Mukachevo. 240 p.

11. Kasyarum, S.O. (2008). Modeliuvannia zmistu navchalnoho materialu [Modeling the content of the educational material]. Pedahohichnyi almanakh - Pedagogical Almanac. Kherson. No. 3, 49-54.

12. Koval, L. Profesiina pidhotovka maibutnikh uchyteliv u konteksti rozvytku suchasnoi pochatkovoi osvity: tekhnolohichnyi pidkhid [Professional training of future teachers in the context of development of modern elementary education: technological approach].

13. Kolupayeva, A.A, Sophia, N.S., \& Nida, Yu.M. (2007). Inkliuzyvna shkola: osoblyvosti orhanizatsii ta upravlinnia [Inclusive school: features of organization and management]. Kyiv. 128 p.

14. Kraevsky, V.V., \& Polonsky, V.M. (2001). Metodolohiia dlia vykladacha: teoriia i praktyka. [Methodology for a teacher: theory and practice]. Volgograd, $324 \mathrm{p}$.

15. Kurakin, A.T., \& Novikova, L.I. (1970) Pro systemnyi pidkhid u vyvchenni problem osvity. [On the systematic approach in the study of education problems]. Radianska pedahohika - Soviet pedagogy. No. 10, 99-108.

16. Makarenko, A.S. (1986). Pedahohichni kompozytsii [Pedagogical Compositions]. Moscow: Pedagogics, $336 \mathrm{p}$. 
17. Maslov, V.I. (2008). Modeliuvannia teoretychnoi ta praktychnoi diialnosti v pedahohitsi. [Modeling in theoretical and practical activities in pedagogy]. Pisliadyplomna osvita v Ukraini-Postgraduate education in Ukraine. No. 1, 3-9.

18. Matrosova, I.G. (2008) Model poetapnoho formuvannia tekhnolohichnoi kompetentnosti sered studentiv-tekhnolohiv u protsesi vykladannia spetsialnykh dystsyplin [Model of phased formation of technological competence among students-technologists in the process of teaching special disciplines]. Pedahohichnyi almanakh - Pedagogical Almanac. No. 3, 124-129.

19. Monakhov, V.M. (2001) Pedahohichne proektuvannia - suchasni zasoby dydaktychnoho doslidzhennia [Pedagogical designing - modern tools of didactic research]. Shkilni tekhnolohii - School technologies. No. 5, 75-89.

20. Natsionalna stratehiia rozvytku osvity v Ukraini do 2021 roku. [National strategy for the development of education in Ukraine until the year 2021].

\section{Позднякова О.Л. Проблема формування педагогічного моделювання як профе- сійного портрету виховної системи освітньо-реабілітаційних закладів.}

\section{Анотація}

У статті розкрито проблему функиіонування сучасної виховної системи освітньореабілітаційних закладів в умовах динамічних змін освітньої сфери. Здійснено теоретичний аналіз базових понять, щзо показав неоднозначність деяких положень методології моделювання освітніх систем, зокрема виховних. Окреслено методологічні засади проиесу моделювання виховної системи освітньо-реабілітаційного закладу. Проведено обгрунтування понять «моделювання» та «педагогічне моделювання». Пояснено різницю між ними. Зібрано наукові дослідження та праџі визначих педагогів у ціий сфері. Запропоновано системний підхід, щзо дасть змогу розглядати модельований педагогічний об'єкт як певну иілісність, яка постає складною та багатоаспектною педагогічною системою.

Ключові слова: моделювання; педагогічне моделювання; модель; педагогічна модель; виховний процес; методологічна основа; принципи педагогіки.

\section{Позднякова О.Л. Проблема формирования педагогического моделирова- ния как профессионльного портрета воспитательной системы образовательно- реабилитационных учреждений.}

Аннотация

В статье раскрыта проблема функционирования современной воспитательной системь учебно-реабилитационных учреждений в условиях динамических изменений образовательной сферы. Осуществлен теоретический анализ базовых понятий, который показал неоднозначность некоторых положений методологии моделирования образовательных систем, в том числе воспитательных. Определены методологические основы процесса моделирования воспитательной системы образовательно-реабилитационного учреждения. Проведен анализ и толкование понятий «моделирование» и «педагогическое моделирование». Рассматриваются различия между ними. Собраны научные исследования и работы ведущих педагогов этой сферы, а также предложен системный подход, позволяющий рассматривать моделируемый педагогический объект как некую иелостность, которая выступает сложной и многоаспектной педагогической системой.

Ключевые слова: моделирование; педагогическое моделирование; модель; педагогическая модель; образовательный процесс; современное образовательное учреждение; методологическая основа; принщипь педагогики. 